\title{
Financial Statement Management, Liability Reduction and Asset Accumulation: An Application of Goal Programming Model to a Nigerian Bank
}

\author{
Ajibola Arewa ${ }^{1}$, John Ayodele Owoputi ${ }^{2} \&$ Lezaasi Lenee Torbira ${ }^{3}$ \\ ${ }^{1}$ Department of Accounting and Finance, Faculty of Management Sciences, Lagos State University, Lagos, Nigeria \\ ${ }^{2}$ Department of Banking and Finance, School of Business, Rusfus Giwa Polytechnic Owo, Ondo State, Nigeria \\ ${ }^{3}$ Department of Finance and Banking, Faculty of Management Sciences, University of Port Harcourt, Port Harcourt, \\ River State, Nigeria \\ Correspondence: Ajibola Arewa, Department of Accounting and Finance, Faculty of Management Sciences, Lagos \\ State University, Lagos, Nigeria. Tel: 80-6-096-2048. E-mail: ajibolaarewa@yahoo.com
}

Received: July 5, 2013

doi:10.5430/ijfr.v4n4p83
Accepted: August 15, 2013

Online Published: October 8, 2013

URL: http://dx.doi.org/10.5430/ijfr.v4n4p83

\begin{abstract}
This paper examines the management of the financial statement of UBA using goal programming (GP) technique. The data are collected from the annual financial statement of the bank to cover a period of 2007 to 2011. Six goals are identified in the bank: goal (1) (asset accumulation); goal 2 (liability reduction); goal 3 (shareholders' wealth); goal 4 (earning); goal 5 (profitability); and goal 6 (optimum management of the items in the financial statement). Applying POM-QM Version 3 software, the solution generated reveals that besides goal 2, all other goals are attainable by the bank. It is not therefore possible for the bank to reduce its liabilities, for the sake of reducing or increasing the other items of its financial statement. Based on this, it is concluded that the bank should convert its liabilities to earning assets quickly or as much as possible.
\end{abstract}

Keywords: management, asset, liability, earning, profitability, shareholders' wealth, GP, UBA

\section{Introduction}

Basically, financial statement management refers to day to day strategic procedure by which an institution manages its assets and liability in order to respond to its liquidity preference and desired profit. During the periods of 1940s up to 1950s, banks had abundant funds at their custodies in the forms of demand and savings deposits. Since these deposits are relatively cheap to acquire, banks developed strategies to make efficient uses of these funds. Thus, their focus was on asset management. However, the availability of cheap funds starts declining over time which consequently forces banks to give attention to liability management.

It is apparently obvious that different goals have been considered to be the fulcrums of managing the balance sheet of a bank. For instance, Macennskiene (2000) maintains that banks engage in asset-liability management to achieve three main goals: to ensure high profitability, to maintain desired liquidity level and to ensure security. Also, Angele (2008) contends that the strategy of maintaining bank asset and liability allows for achieving banking harmony which reflects in sound performance that actualizes profit maximization and attainment of desired liquidity preference. In a recent time, Machiel (2011) posits that efficient management of a bank's balance sheet leads to the goal of maximizing returns and simultaneously taking into account conflicting goals such as minimizing risk, subject to regulatory and managerial constraints.

In essence, the typical strategic goals of a bank are: return maximization, risk minimization, liquidity/capital adequacy and growth in market share. Since these goals are in conflict with each other simple linear programming will not suffice and one has to resort to multi objective approaches like goal programming (Machiel, 2011). Therefore, goal programming is an extension of simple linear programming with adequate mathematical features to handle multi objective conflicts or goals. Even Ignizio (1978) agrees that goal programming is a proposed mathematic model/approach for analyzing a situation with multi-purpose objectives. In view of these, we are primarily driven to employ goal programming model with the aims of: (1) analyzing the structure and the variations 
in the proportions of items in the selected Nigerian bank financial statement and (2) revealing the optimum proportions of these items that could achieve sustainable profits for the shareholders of the bank. The remaining parts of this paper are outlined as follows: literature review, methodology and data, interpretation of results, conclusion and recommendations.

\section{Literature Review}

\subsection{The Goal Programming Model}

Chowdary and Slomp (2002) saw goal programming as an appropriately powerful and flexible technique for decision making analysis of a modern decision maker who is burdened with achieving multiple conflicting objectives under complex environmental constraints. The extensive surveys of goal programming by (Tamiz, Jones \& Romero, 1998) and (Aouni \& Kettani, 2001) have reflected this. Thus, goal programming model handles multiple goals in multiple dimensions. Taha (2003) confirmed that goal programming technique is for solving multiple-objective problems and the aim is to convert the original multiple objective into a single goal. He concluded that the weights and the pre-emptive methods convert the multiple goals into a single objective function stating that these methods do not generally produce the same solution. However, neither method is superior to the other because each technique is designed to satisfy certain decision making preferences.

Hillier and Lierberman (2001) pointed that goal programming problems can be classified according to the type of mathematical programming models that they fit except for having multiple goals instead of a single objective. According to them, the case of non pre-emptive goal programming, all the goals are of roughly comparable importance but in the case of pre-emptive goal programming, there is a hierarchy of priority levels for the goals. They concluded that goal programming and its solution procedures provide an effective way of dealing with problems where management wishes to strive towards several goals simultaneously. The central key here is to formulate a technique of introducing auxiliary variables that enable the conversion of the problem into a linear programming format. Finally, they stated that to complete the conversion of the goal programming problem to a linear programming model, we must incorporate the definitions of the deviational variables $\mathrm{di}+$ and di- directly into the model because the simplex method considers only the objective function and the constraints that constitute the model.

Romero and Rehman (2003) said both Lexicographic Goal Programming (LGP) and Weighted Goal Programming (WGP) are widely used as goal programming variants. These variants lie heavily on the great amount of information that these goals target, weights and the pre-emptive ordering of preferences. Diaz-Balteiro and Romero (2003) affirmed that weighted goal programming (WGP) and lexicographic goal programming (LGP) can be mixed in a model. Abdulaziz and Majri (2001) considered the control of drinking water supply goal as a random variable. Other recent applications of various formulations of goal programming have been presented by Carrizosa and Romero (2001) and Leung (2001). Lam and Moy (2002) reviewed the intersection of goal programming and Discriminant Analysis beginning with Freed and Glover (1981).

\subsection{Application of Goal Programming in Banks}

Chambers and Charnes (1961) developed the first model of assets and liabilities as deterministic linear programming model. Their model relatively concerned with determining an optimal portfolio for a bank over several periods and the level of existing risk in bank's portfolio was mentioned as constraints in the model. However, their investigations into the optimum proportion required by banks to meet the goals of their shareholders were continued by (Cohen \& Hammer, 1967), (Robertson, 1972), (Lifson \& LoBlackman, 1973) and (Fielitz \& Loeffler, 1979). Also, Chambers and Charnes ' model in facing with disaggregation; unreliability and lack of dynamism were treated differently but all of them had a common feature, which were specifically considered as the profitability in target function and constraints in linear form. Eatman and Sealey (1979) used a multi-objective linear programming's model which considered three objectives: net profit, capital adequacy ratio and the ratio of risky assets to capital, to analyze the variations of these items and to reveal the proportions needed to maximize the wealth of shareholders. In an equal vein, Giokas and Vassiloglou (1991) presented a Goal Programming model using Greek as a case study and relatively large banks were selected for their study. They concluded that management should pursue the goal of maximizing revenues alongside with optimum allocation of risks in their capital and other bank's goals such as market share and increasing the amount of loans and deposits.

Korhonen (2001) presented a practical application to Goal Programming Model which included three stages in one of the Finland Banks as programming model of bank's dynamic portfolio with several scenarios and multiple purposes. He incorporated the goals to comprise: an expected profit, liquidity risk, grows of customer relationships, 
capital adequacy and so on. Also, two groups of variables, deterministic variables and probabilistic variables were surveyed in the model. Making scenario based on probabilistic volatility of probabilistic variables is reviewed in twenty-one scenarios and according to economic conditions and probable changes; his overall emphases is to analyze and reveal the optimum proportion of the bank identified items. Kosmidou and Zopounidi (2004) carried out one of the applied researches in management literature which was titled: "A Multicriteria Methodology for Bank's Asset and Liability Management". They examined 2000 year's balance sheet of one of the Greek banks with the aid of Goal Programming and based on three interest rates, bond, deposits and facilities rates, some simulation analyses were conducted until according to the most probable economic condition the best combination with highest return was selected. Sohela, Mehrzed and Hadi (2013) designed a mathematical model in order to select the optimum management of assets and liabilities of one of the banks in Mellat. Their results showed that it was possible to design model of optimum management of assets and liabilities of the selected bank so as to determine suitable structure for items of its balance sheet and extend the outcomes to the management of balance sheet items of other banks.

\section{Data Source and Preparation}

The data employed in this work are sourced from the annual financial statement of the bank selected for our study. The United Bank of Africa (UBA) is chosen and the data relating to its total assets, liabilities, shareholders' funds, earnings and profitability for a period of 2007 to 2011 are collected and prepared using coding and weighting methods as follows:

Table 1. UBA summarized financial statement for period 2007 to 2011

\begin{tabular}{lllllll}
\hline Goal & Year & & & \\
& 2007 & 2008 & 2009 & 2010 & 2011 & \\
& $(\mathrm{~N}, 000)$ & $(\mathrm{N}, 000)$ & $(\mathrm{N}, 000)$ & $(\mathrm{N}, 000)$ & $(\mathrm{N}, 000)$ & Total \\
Asset & 1191042000 & 1673333000 & 1548281000 & 1617696000 & 1864457000 & 7894809000 \\
Liability & 1142207000 & 1478052000 & 1361452000 & 143827000 & 1682301000 & 7102322000 \\
Shareholders fund & 48835000 & 195231000 & 186829000 & 179426000 & 182156000 & 792471000 \\
Earning & 109512000 & 189506000 & 246725000 & 18518600 & 198725000 & 929654000 \\
Profit & 2154000 & 41239000 & 2113000 & 668000 & 797000 & 66357000 \\
Total & 3776985958 & 3577361000 & 3345440000 & 21268030000 & 3928430000 & 1373812396 \\
\hline
\end{tabular}

Source: Author's Computation

The Coding:

Table 2. UBA summarized financial statement in coded values for years 2007 to 2011

\begin{tabular}{lcccccc}
\hline Goal & \multicolumn{7}{l}{ Yearly value of item in Trillion Naira } & & & \\
\hline & 2007 & 2008 & 2009 & 2010 & 2011 & Total \\
Asset & 1.191 & 1.673 & 1.548 & 1.618 & 1.864 & 7.894 \\
Liability & 1.142 & 1.478 & 1.361 & 1.437 & 1.682 & 7.1 \\
Share holders Fund & 0.048 & 0.195 & 0.187 & 0.179 & 0.182 & 0.791 \\
Earning & 0.11 & 0.19 & 0.247 & 0.185 & 0.199 & 0.931 \\
Profit & 0.022 & 0.041 & 0.002 & 0.0007 & 0.0008 & 0.067 \\
Total & 2.513 & 3.577 & 3.345 & 3.42 & 3.928 & 16.783 \\
\hline
\end{tabular}

Source: Author's Computation

\section{Allocation of Weights to the Goals:}

We assign weight according to the value of an item in table such that the item with the highest value attracts the highest weight. Thus, the table is represented as: 
Table 3. UBA summarized financial statement in coded values with weights for years 2007 to 2011

\begin{tabular}{lrrrrrr}
\hline Goal & \multicolumn{7}{l}{ Weight in Relation to value of the Goal } \\
\hline & 2007 & 2008 & 2009 & 2010 & 2011 & Total \\
Asset & 1.191 & 1.673 & 1.548 & 1.18 & 1.864 & 7.894 \\
Liability & 1.142 & 1.478 & 1.361 & 1.437 & 1.682 & 7.1 \\
Share holders Fund & 0.048 & 0.195 & 0.187 & 0.179 & 0.182 & 0.791 \\
Earnings & 0.11 & 0.19 & 0.247 & 0.185 & 0.199 & 0.931 \\
Profit & 0.022 & 0.041 & 0.002 & 0.0007 & 0.0008 & 0.067 \\
Total & 2.513 & 3.577 & 3.345 & 3.42 & 3.928 & 16.783 \\
\hline
\end{tabular}

Source: Author's Computation

\section{Methodology}

The formulation of a goal programming methodology involves essentially the following steps:

Determination of the decision variables, specification of the goal types and their targets (the goal types can be either one-way for two-way goal), stating the pre-emptive factors or priorities, determining the weights, the minimization objective functions of the deviation variables should be stated, stating the constraint and non-negativity functions and lastly, ensure that the model is stated in a way that it reflects the preferences of the decision maker(s). Thus, generally there are two methods or algorithms for solving goal programming problems. These are: Weights method and pre-emptive method

\subsection{The Weight Method}

This method of goal programming can be expressed as:

$$
\begin{gathered}
\text { Maximize } Z=\sum_{\mathrm{t}=1}^{\mathrm{n}}\left[\left(\mathrm{W}_{\mathrm{t}}^{\mathrm{t}}+\mathrm{W}_{\mathrm{t}}^{-}\right) \operatorname{dev}_{\mathrm{t}}\right] \\
\mathrm{St} \\
\sum_{\mathrm{f}}^{\mathrm{k}}\left(\mathrm{X}_{\mathrm{tf}} \mathrm{Y}_{\mathrm{f}}+\operatorname{dev}_{\mathrm{t}}^{\mathrm{t}}-\operatorname{dev}_{\mathrm{t}}^{-}\right)=\mathrm{tL}_{\mathrm{t}}
\end{gathered}
$$

Note that:

$$
\begin{array}{ll}
\mathrm{t}=1,2, & \mathrm{n} \\
\mathrm{f}=1,2, & \mathrm{k} \\
\operatorname{dev}_{\mathrm{t}}^{\mathrm{t}}, \operatorname{dev}_{\mathrm{t}}^{-}, \mathrm{Y}_{\mathrm{f}} \geq 0 &
\end{array}
$$

Where: $\mathrm{W}_{\mathrm{t}}^{+}$is the positive parameter representing the decision makers' preferences

$\mathrm{W}_{\mathrm{t}}{ }_{\mathrm{t}}$ is the negative parameter representing the decision makers' preferences

$\operatorname{dev}_{\mathrm{t}}{ }^{+}$represents the positive deviation variable from overachieving $\mathrm{t}^{\text {th }}$ goals

$\operatorname{dev}_{\mathrm{t}}^{-}$represents the negative deviation variable from underachieving $\mathrm{t}^{\text {th }}$ goals

$\mathrm{Y}_{\mathrm{f}}$ represents decision variable

$\mathrm{X}_{\mathrm{tf}}$ represents the parameter of the decision variable

$\mathrm{tL}_{\mathrm{t}}$ represents the target or aspiration level

$n$ represents the number of weight

And $\mathrm{k}$ represents the number of goals

Note that the values of $\mathrm{W}_{\mathrm{t}}^{+}$and $\mathrm{W}_{\mathrm{t}}^{-}$are determined subjectively in relation to the priority given to the deviational variables.

\subsection{The Pre-emptive Method}

This method is analogously known as lexicographic goal programming method which allows the decision makers to rank the goals in order of preference or importance. Therefore, this model is optimized taking one goal at a time before the other such that the highest priority is given to the most preferred goal. The mathematical representation of this model can be expressed as:

$$
\underset{\mathrm{t}=1,2}{\operatorname{Maximize} \mathrm{Z}=\sum_{\mathrm{t}=1}^{\mathrm{n}}\left[\lambda_{\mathrm{t}}\left(\operatorname{dev}_{\mathrm{t}}^{+}+\operatorname{dev}_{\mathrm{t}}^{-}\right)\right]}
$$


St

Equations 2 and 3 above.

Where: $\lambda_{t}$ is the pre-emptive factor associated with each competitive goal in order of preference (i.e. $\lambda_{1}, \lambda_{2}$, $\left.\lambda_{3} \ldots \ldots \ldots \ldots \ldots \ldots \ldots, \lambda_{\mathrm{n}}\right)$

Kwak, schnierderjams and Warkenstin (1991) proved that the pre-emptive or lexicographic goal programming can be combined with weights goal programming in solving typical goal programming problems. This combination gives rise to the following specification.

$$
\text { Maximize } \mathrm{Z}=\sum_{\mathrm{t}=1}^{\mathrm{n}} \lambda_{\mathrm{t}} \sum_{\mathrm{t}=1}^{\mathrm{n}}\left(\mathrm{W}_{\mathrm{tv}}{ }^{+} \operatorname{dev}_{\mathrm{t}}^{+}+\mathrm{W}_{\mathrm{tv}}{ }^{-} \mathrm{dev}_{\mathrm{t}}{ }^{+}\right)
$$

St

Equation 2 and 3 above

Note that $\mathrm{v}=1,2,3, \ldots$

Other variables are as defined above.

Adopting this model in our study for UBA gives rise to the formulation of the following goal programming model.

\section{Goal Programming Model Formulation}

Formulating this model involves stating the aspiration level or the target value of each of the goals. Thus, the goal statements of the Bank are as follow:

(i) Increase the yearly size of asset by at least $1.1 \mathrm{~T}$

(ii) Decrease the yearly size of liability by at most $\$ 5.7 \mathrm{~T}$

(iii) Increase the yearly value of shareholders wealth by at least $\mathrm{N0.2 \textrm {T }}$

(iv) Increase the yearly gross earnings by at leastN0.9T

(v) Increase the yearly profit attributed to share holders by at least N0.04T

(vi) Increase the proportion or weight of the values of the items in the financial statement by at least N5.5T

The decision variables in the model are:

$\mathrm{Y}_{1}, \mathrm{Y}_{2}, \mathrm{Y}_{3}, \mathrm{Y}_{4}$, and $\mathrm{Y}_{5}$ for the five years, where

$\mathrm{Y}_{1}$ represents the amount in the 2007 financial statement

$\mathrm{Y}_{2}$ represents the amount in the 2008 financial statement

$\mathrm{Y}_{3}$ represents the amount in the 2009 financial statement

$\mathrm{Y}_{4}$ represents the amount in the 2010 financial statement

$\mathrm{Y}_{5}$ represents the amount in the 2011 financial statement

The goal programming model can now be mathematically expressed as follows:

5.1 Goal Programming for UBA

$1.191 \mathrm{x}_{1}+1.673 \mathrm{x}_{2}+1.548 \mathrm{x}_{3}+18 \mathrm{x}_{4}+1.864 \mathrm{x}_{5} \geq 7.894$ (Asset Accumulation constraint)

$1.142 \mathrm{x}_{1}+1.478 \mathrm{x}_{2}+1.361 \mathrm{x}_{3}+1.437 \mathrm{x}_{4}+1.682 \mathrm{x}_{5} \leq 7,100$ (liability constraint)

$0.0489 \mathrm{x}_{1}+0.195 \mathrm{x}_{2}+0.189 \mathrm{x}_{3}+0.179 \mathrm{x}_{4}+0.182 \mathrm{x}_{5} \geq 0.791$ (shareholders wealth constraint)

$0.110 \mathrm{x}_{1}+0.90 \mathrm{x}_{2}+0.247 \mathrm{x}_{3}+0.185 \mathrm{x}_{4}+0.199 \mathrm{x}_{5} \geq 0.931$ (earning constraint)

$0.022 \mathrm{x}_{1}+0.041 \mathrm{x}_{2}+0.002 \mathrm{x}_{3}+0.0007 \mathrm{x}_{4}+0.0008 \mathrm{x}_{5} \geq 0.067$ (profitability constraint)

$2.513 \mathrm{x}_{1}+3.577 \mathrm{x}_{2}+3.345 \mathrm{x}_{3}+3.420 \mathrm{x}_{4}+3.928 \mathrm{x}_{5} \geq 16.783$ (financial statement managing constraint)

$\mathrm{x}_{1}, \mathrm{x}_{2}, \mathrm{x}_{3}, \mathrm{x}_{4}, \mathrm{x}_{5}, \geq 0$ (non negativity constraint)

Changing from the conical or inequality forms to standardized forms gives rise to the following equations

$$
\operatorname{Max}(\mathrm{Z})=8.35 \mathrm{dev}_{1}{ }^{+}+6.68 \mathrm{dev}_{2}^{-}+3.34 \mathrm{dev}_{3}{ }^{+} 5.01 \mathrm{dev}_{4}^{+}+1.67 \mathrm{dev}_{5}^{+}+10.02 \mathrm{dev}_{6}^{+} \text {(objective function) }
$$

st

$$
1.191 \mathrm{x}_{1}+1.673 \mathrm{x}_{2}+1.548 \mathrm{x}_{3}+18 \mathrm{x}_{4}+1.864 \mathrm{x}_{5}+\operatorname{dev}^{-}-\operatorname{dev}^{+}=7.894
$$




$$
\begin{gathered}
1.142 \mathrm{x}_{1}+1.478 \mathrm{x}_{2}+1.361 \mathrm{x}_{3}+1.437 \mathrm{x}_{4}+1.682 \mathrm{x}_{5}+\mathrm{dev}^{-}-\mathrm{dev}^{+}=7,100 \\
0.048 \mathrm{xa}_{1}+0.195 \mathrm{x}_{2}+0.189 \mathrm{x}_{3}+0.179 \mathrm{x}_{4}+0.182 \mathrm{x}_{5}+\mathrm{dev}^{-}-\mathrm{dev}^{+}=0.791 \\
0.110 \mathrm{x}_{1}+0.90 \mathrm{x}_{2}+0.247 \mathrm{x}_{3}+0.185 \mathrm{x}_{4}+0.199 \mathrm{x}_{5}+\operatorname{dev}^{-}-\operatorname{dev}^{+}=0.931 \\
0.022 \mathrm{x}_{1}+0.041 \mathrm{x}_{2}+0.002 \mathrm{x}_{3}+0.0007 \mathrm{x}_{4}+0.0008 \mathrm{x}_{5}+\operatorname{dev}^{-}-\operatorname{dev}^{+}=0.0 \\
2.513 \mathrm{x}_{1}+3.577 \mathrm{x}_{2}+3.345 \mathrm{x}_{3}+3.420 \mathrm{x}_{4}+3.928 \mathrm{x}_{5}+\operatorname{dev}^{-}-\operatorname{dev}^{+}=16.783 \\
\mathrm{x}_{1}, \mathrm{x}_{2}, \mathrm{x}_{3}, \mathrm{x}_{4}, \mathrm{x}_{5}, \operatorname{dev}_{1}, \operatorname{dev}_{2}, \operatorname{dev}_{3}, \operatorname{dev}_{4}, \operatorname{dev}_{5}, \operatorname{dev}_{6}=0
\end{gathered}
$$

\begin{tabular}{|c|c|c|c|c|c|c|c|c|c|c|c|c|c|c|c|c|c|c|}
\hline \multicolumn{19}{|l|}{ Basic } \\
\hline Variable & $\mathrm{x} 1$ & $\mathrm{x} 2$ & $\mathrm{x} 3$ & $\mathrm{x} 4$ & $\mathrm{x} 5$ & $x 6$ & $\mathrm{x} 7$ & $\mathrm{x} 8$ & $\mathrm{x} 9$ & $\mathrm{x} 10$ & $\mathrm{x} 11$ & $\mathrm{x} 12$ & $\mathrm{x} 13$ & $\mathrm{x} 14$ & $\mathrm{x} 15$ & $\mathrm{x} 16$ & $\mathrm{x} 17$ & $\begin{array}{l}\text { How } \\
\text { much }\end{array}$ \\
\hline \multicolumn{19}{|l|}{ Variable } \\
\hline Name & & & & & & $\mathrm{d} 1+$ & $\mathrm{d} 2+$ & $\mathrm{d} 3+$ & $\mathrm{d} 4+$ & d5+ & d6+ & d1- & d2- & d3- & d-4 & d-5 & d-6 & \\
\hline $\operatorname{Max}(Z)$ & 0 & 0 & 0 & 0 & 0 & 8.35 & 0 & 5.01 & 3.34 & 1.67 & 10.02 & 0 & 6.68 & 0 & 0 & 0 & 0 & \\
\hline \multicolumn{19}{|l|}{ Constraint } \\
\hline-1 & 1.191 & 1.673 & 1.548 & 1.189 & 1.864 & -1 & 0 & 0 & 0 & 0 & 0 & 1 & 0 & 0 & 0 & 0 & 0 & 7.894 \\
\hline \multicolumn{19}{|l|}{ Constraint } \\
\hline-2 & 1.142 & 1.478 & 1.361 & 1.437 & 1.682 & 0 & -1 & 0 & 0 & 0 & 0 & 0 & 1 & 0 & 0 & 0 & 0 & 7.100 \\
\hline \multicolumn{19}{|l|}{ Constraint } \\
\hline-3 & 0.048 & 0.195 & 0.189 & 0.179 & 0.182 & 0 & 0 & -1 & 0 & 0 & 0 & 0 & 0 & 1 & 0 & 0 & 0 & 0.791 \\
\hline \multicolumn{19}{|l|}{ Constraint } \\
\hline-4 & 0.11 & 0.909 & 0.242 & 0.135 & 0.199 & 0 & 0 & 0 & -1 & 0 & 0 & 0 & 0 & 1 & 0 & 0 & 0 & 0.931 \\
\hline \multicolumn{19}{|l|}{ Constraint } \\
\hline-5 & 0.022 & 0.041 & 0.002 & 0.0007 & 0.0008 & 0 & 0 & 0 & 0 & -1 & 0 & 0 & 0 & 0 & 0 & 1 & 0 & 0.067 \\
\hline \multicolumn{19}{|l|}{ Constraint } \\
\hline-6 & 2.513 & 3.35 & 3.42 & 3.42 & 3.928 & 0 & 0 & 0 & 0 & 0 & -1 & 0 & 0 & 0 & 0 & 0 & 1 & 16.783 \\
\hline
\end{tabular}

\section{Inputting Data in the Goal Programming Algorithm}

The data used in the formulation of the goal programming problem are inputted in the following table.

Table 4. Inputted data for UBA GP formulation

Note: $\mathrm{a}_{6}=\mathrm{d}_{1}^{+}, \mathrm{a}_{7}=\mathrm{d}_{2}^{+}, \mathrm{a}_{8}=\mathrm{d}_{3}^{+}, \mathrm{a}_{9}=\mathrm{d}_{4}^{+}, \mathrm{a}_{10}=\mathrm{d}_{5}^{+}, \mathrm{a}_{11}=\mathrm{d}_{6}^{+}, \mathrm{a}_{12}=\mathrm{d}_{1}^{-}, \mathrm{a}_{13}=\mathrm{d}_{2}^{-}, \mathrm{a}_{14}=\mathrm{d}_{3}^{-}, \mathrm{a}_{15}=\mathrm{d}_{4}^{-}, \mathrm{a}_{16}=\mathrm{d}_{5}^{-}, \mathrm{a}_{17}=\mathrm{d}_{6}^{-}$

Source: Author's Computation

\section{Solution and Discussion of Findings}

The version 3 of POM-QM is applied on table 4 to solve the goal programming problem formulated for UBA. The solutions obtained are presented as:

\subsection{Solution}

$\mathrm{Z}=4.94, \mathrm{x}_{1},=0, \mathrm{x}_{2}=1.46, \mathrm{x}_{3}=0, \mathrm{x}_{4}=4.59, \mathrm{x}_{5}=0, \mathrm{~d}_{1}^{+}=0, \mathrm{~d}_{2}^{+}=1.65, \mathrm{~d}_{3}^{+}=0.31, \mathrm{~d}_{4}^{+}=1.01, \mathrm{~d}_{5}^{+}=0, \mathrm{~d}_{6}^{+}=3.79, \mathrm{~d}_{1}^{-}$

$=0, \mathrm{~d}_{2}{ }^{-}=0, \mathrm{~d}_{3}{ }^{-}=0, \mathrm{~d}_{4}{ }^{-}=0 \mathrm{~d}_{5}{ }^{-}=0, \mathrm{~d}_{6}{ }^{-}=0$

\subsection{Discussion of Findings}

The findings reveal that the value of $\mathrm{z}$ is not equal to zero. This means that the optimum solution satisfies goals 1,2 , $3,4,5$ and 6 which are asset accumulation, shareholder wealth, earning, and profitability maximization goals. But however, it fails to satisfy goal 2 which is liability minimization goal. The value of $\mathrm{d}_{2}{ }^{+}=1.65$. This indicates that the target of liability goal $\$ 7.1$ Trillion is overstated by $\$ 1.65$ Trillion, for $\mathrm{d}_{3}{ }^{+}=0.31$ means that the aspiration level of the shareholders' wealth of $\$ 0.791$ Trillion exceeds the shareholders' wealth goal by $\$ 0.31$ Trillion. Likewise, the earning and financial statement management levels which are 0.931 and 16.783 Trillions are respectively overstated by $\$ 1.01$ and $\$ 3.79$ Trillion. On the contrary, the asset accumulation goal and profitability goal of at least $\$ 7.894$ and $\$ 0.06$ Trillions are not violated in this bank as $\mathrm{d}_{1}{ }^{+}$and $\mathrm{d}_{1}{ }^{-}$are both zero and $\mathrm{d}_{5}{ }^{+}$and $\mathrm{d}_{5}{ }^{-}$are both zero. 
Finally, the value of $\mathrm{z}$ which is $\$ 4.94$ Trillion implies that the bank should source capital up to the tune of 44.94 Trillion annually from within or other sources apart from liability to flow in its financial statement; in order to fulfill the liability reduction goal. Hence, if the bank could not generate about $\$ 4.94$ Trillion from other sources besides liability, it is impossible for the bank management to attain the goal of liability reduction. So, the liability of the bank will keep on increasing as long as it is willing to fill the other goals (i.e. 1, 2, 3, 4, 5, and 6).

\section{Conclusion}

The study investigates the management of the items in the financial statement of UBA using goal programming model. The results depict that the goals formulated can be maximally attained besides the goal of liability reduction. Thus, our finding is in close tandem with the works of (Angele, 2008) and (Macheiel, 2011). Without equivocation, it can be concluded that UBA and other deposit money banks in Nigeria thrive efficiently on liability accumulation yearly through deposite mobilization activities; therefore, the goal of reducing liability can never be achieved in Nigerian banking sector.

\subsection{Recommendations}

- It is recommended that UBA should effectively managed their acquired liabilities by turning them into assets

- The aspiration levels of some goals such as earnings and shareholders' wealth should be abated.

- In all a minimum cash flow of $\$ 4.94$ Trillion should permeate in the financial statement of the bank to allow for sound liquidity status.

- Finally, we recommend that the conclusion, based on the goal programming solution computed for UBA, should be upheld in every other indigenous bank.

\section{References}

Abdelaziz, B.F., \& Mejiri, S. (2001). Application of goal programming in multi-objective reservoir operation model in Tunisia. European Journal of Operational Research, 133(2), 352-361. http://dx.doi.org/10.1016/S0377-2217(00)00303-9

Angele, L. (2008). Analysis of chosen strategies of asset and liability management in commercial banks. Journal of Economics of Engineering Decision, (2), 57.

Aouni, B., \& Kettani, O. (2001). Goal Programming Model: A glorious history and promising future. European Journal of Operations Research, 133(2), 1-7. http://dx.doi.org/10.1016/S0377-2217(00)00294-0

Chambers, D., \& Charnes, A. (1961). Inter-temporal analysis and optimization of bank portfolios. Management Science, 7(11), 393-409. http://dx.doi.org/10.1287/mnsc.7.4.393

Chowdary, B.V., \& Slomp, J. (2002). Production planning under dynamic product environment: A multi-objective Goal Programming Approach. Management and Organization, 1-12.

Cohen, K. J., \& Hammer, F.S. (1967). Linear programming and optimal bank asset management decision. Journal of Finance, 22, 42-61.

Diaz-Balteiro, L., \& Romero, C. (2003). Forest Management Optimization Models when carbon captured is considered: A Goal Programming Approach. Forest Ecology Management, 174, 447-457. http://dx.doi.org/10.1016/S0378-1127(02)00075-0

Eatman, L., \& Sealey Jr. (1979). A multi-objective Linear Programming Model for commercial bank balance sheet management. Journal of Bank Research, 9, 227-236.

Fielitz, D., \& Loeffler, A. (1979). A Linear Programming Model for commercial bank liquidity management. Financial Management, 8(3), 44-50. http://dx.doi.org/10.2307/3665037

Freed, N., \& Glover, F. (1981). Simple but powerful Goal Programming Models for discriminate problems. European Journal of Operations Research, 7, 44-66. http://dx.doi.org/10.1016/0377-2217(81)90048-5

Giokas, D., \& Vassiloglou, M. (1991). A Goal Programming Model for bank assets and liabilities. European Journal of Operations Research, 50, 48-60. http://dx.doi.org/10.1016/0377-2217(91)90038-W

Hillier, F.S., \& Lieberman, G.J. (2001). Introduction to Operations Research (Seventh ed.). McGraw- Hill, New York, 7, 331-340. 
Korhonen, A. (2001). Strategic ${ }^{\circledR}$ nancial management in a multinational ${ }^{\circledR}$ nancial conglomerate: A multiple goal stochastic programming approach. European Journal of Operational Research, 128, 418-434. http://dx.doi.org/10.1016/S0377-2217(99)00366-5

Kosmidou K., \& Zopounidis, C. (2004). Goal programming techniques for bank asset liability management. Kluwer Academic Publishers.

Kwak, N. K., Schnierderjams, M. J., \& Warkenstin, K. S. (1991). An application of linear goal programming to the marketing distribution. European Journal of Operations Research, 52, 334-344. http://dx.doi.org/10.1016/0377-2217(91)90168-U

Lam, K. P., \& Moy, J. W. (2002). Combination discriminant methods in solving classification problems in two-group discriminant analysis. European Journal of Operational Research, 138, 294-301. http://dx.doi.org/10.1016/S0377-2217(01)00247-8

Lifson, K.A., \& Blackman, B.R. (1973). Simulation and optimization models for asset deployment and funds sources balancing profit liquidity and growth. Journal of Bank Research, 4(3), 239-255.

Macennskiene, I. (2000). Banko paskolu portfolio vaidymas tyrimo metodologinai aspektai socialinnai mokslai, (5), 45.

Machiel, K. (2011). A goal programming approach to strategic bank balance sheet management. Center for BMI, North-West University, South African.

Robertson, M. (1972). A bank asset management model. In S. Eilon and T.R. Fowkes (Eds.), Applications of management science in banking and finance (pp. 149-158). Gower Press. Epping. Essex.

Romero, C., \& Rehman, T. (2003). Multiple Criteria Analysis for Agricultural Decisions (Second ed.). Development in Agricultural Economics, 5. Elsevier Science Publishers B.V.

Soheyla, N., Mehizad M., \& Hadi, P.G. (2013). Asset and liability optimal management mathematical modeling for banks. Journal of Basic and Applied scientic Research, 3(1), 484-493.

Taha, H. A. (2003). Operation Research: An Introduction (Seventh ed.). Prentice-Hill delhi, India, 8, 347-360.

Tamiz, M., Jones, D., \& Romero, C. (1998). Goal programming for decision making: An overview of the current state of the art. European Journal of Operational Research, 111, 569-581. http://dx.doi.org/10.1016/S0377-2217(97)00317-2 